\section{The Effect of Intercultural Education on the Ethnocentrism Levels of Prospective Teachers*}

\author{
Selma Aslantaş ${ }^{* *}$
}

\begin{tabular}{ll}
\hline Received: & 12 December 2018 \\
Revised: & 21 February 2019 \\
Accepted: & 27 February 2019 \\
ISSN: 1307-9298 \\
Copyright (C) IEJEE \\
www.iejee.com
\end{tabular}

DOI: 10.26822/iejee.2019450790

\begin{abstract}
In this study; the effects on the ethnocentrism levels of prospective teachers have been examined upon providing education under the scope of intercultural education. The study has been designed as a quasi-experimental design with pre-test, final-test control group. The study took place during the spring semester of 2014-2015 academic year. The study group consists of a total of 118 prospective teachers, 74 of whom (trial group) are students at a public university in Ankara and 44 (control group) from a public university in Niğde. At the beginning and end of the study, the ethnocentrism levels of the prospective teachers have been assessed. The 20-item Ethnocentrism Scale has been used as the data collection tool. In order to interpret the points scored in "Ethnocentrism Scale", an independent sample t-test and "One-Way Covariance" analysis have been used. The research findings indicated a positive oriented change in the ethnocentrism points and between both the trial and control group students' pre- and final test grade averages in the in-group comparisons. However, this positive change was in favour of the trial group in the inter-group comparisons. In other words, the project assignment made by the prospective teachers had a positive impact on the students' ethnocentrism levels.
\end{abstract}

Keywords: Intercultural Education, Ethnocentrism, Teacher Training, Visual Arts Education

\section{Introduction}

As in all parts of life, cultural and social alteration has become one of the important societal factors in uncovering new opinions and ideas in the field of education. Intercultural education has become one of the prominent issues in the field of education as a result of this alteration. As well as the historic and political issues, migration at different levels around the world are among the main factors that are making intercultural education a prominent issue. Common living points have been established as individuals with different habits, cultures and social structures need to live and work together (Banks, 2013; Bennett, 2009; Bleszynska, 2008; Gay, 2014). Furthermore, transformation through technology and knowledge lead to an intense communication everywhere from education to business sector (Kartarı, 2001). At this point, intercultural education has maintained its position within national and international levels. According to Bleszynska (2008), intercultural education is the result of educational and social processes in multicultural societies existing in a globalizing world. This outcome is being expressed in three dimensions:

- Social-Global: The variance of civilization and cultures at a global level and the respect towards this variation, solidarity, and the ability to live peacefully with different cultures, being aware of national and international migration,

- Social-National: Existence of cultural differences and varieties, combatting inequalities that are caused by differences, preventing intercultural disputes,

- Social-Individual: Developing the ability to live in harmony with cultural differences at an individual level, dealing with obstructions such as ethnocentrism, prejudice or xenophobia that limit intercultural relations. Developing intercultural competencies at an individual level. In line with these purposes, Bleszynska (2008) describes the education provided in official or unofficial (common) educational environments under the scope of intercultural education for individuals and societies, social and professional groups, adults, children and teenagers, whether they are migrants or hosts.

Intercultural education is a type of education that includes an interdisciplinary approach aiming to minimize or prevent possible tensions, biases, privileges or stereotyped thoughts that can occur between societies and individuals due to cultural differences. It tries to ensure full and effective participation in life of individuals, whether individually or as part of the society, by developing awareness towards different cultures is one of the aims of intercultural education (Chiriac \& Panciuc, 2015; Perry \& Southwell, 2011; Kartarı, 2001; Üstün, 2011). Intercultural education covers subjects such as examining, learning and understanding different cultures and creating intercultural communication environments. (Kaya \& Aydın, 2014; Tay \& Baş, 2015). Beyond a passive social life, the targets of intercultural education include creating, developing and sustaining means of social understanding and communication that contains different cultures and dialogue and respect between these different cultures (Holm \& Zilliacus, 2009). According to Chiriac \& Panciue (2015), intercultural education is a type of education that expresses interaction between people that possess different ideas and perspectives, religion, language and culture. Essentially, this type of education (such as principles, values, traditions) is also expressing cultural differences and (such as gender, social and economic structure) other differences. Intercultural education assumes the role of social meditation by increasing the productivity of intercultural communication and ensuring tolerance and acceptance between different individuals and societies. Intercultural education aims to provide equal education for each individual in the society in order to en-

\footnotetext{
* A wider summary of this article has been presented as a verbal report at the The Effect of Intercultural Education Based Project Study on the Ethnocentrism Levels of Prospective Teachers: 5th International Congress on Education Programs and Teaching (26-28 October 2017) Muğla/Turkey ** Correspondence Details: Selma Aslantaş, Gazi University, Gazi Faculty of Education, Ankara, Turkey. E-mail: selmaaslantas@hotmail.com
} 
sure their active and complete participation in life through their cultural knowledge, attitude and capabilities (UNESCO, 2006). Many areas, subjects and concepts that comprise the structure of intercultural education help to create studies based on interdisciplinary approach, hence it becomes possible to form educational environments decorated with cultural values (Hofstede, 2001; Kırışoğlu, 2009; Portera, 2008; Tertemiz \& Aslantaş, 2016).

With regards to the formal aspect of intercultural education, Sikorskaya (2017) believes that class programs must be prepared by taking into consideration the teacher's intercultural competency, level of expertise regarding intercultural education, knowledge, level of class receiving the intercultural education and by performing activities in and outside the class. As stressed by Bennett (2009), the need for intercultural competency required for the application of intercultural education is not applicable only for the teachers serving at primary and secondary level institutions but rather it is important for all levels of education including university. On the other hand, looking from a wider perspective, intercultural education refers to the education of all individuals, including all age groups and levels such as young-old, migrant-host, starting from birth and continuing throughout an individual's life (Bleszynska, 2008).

\section{Ethnocentrism}

One of the most important problems affecting communication between individuals, cultures or societies is ethnocentrism (UNESCO, 2008; Üstün, 2011). Defined as the attachment to an ethnical group, the concpt of ethnocentrism is a subjective emotion or attitude where an individual or a group places his/their culture at the centre and interpret the different cultures with their own culture's values (Booth, 2017; De Dreu et al., 2010; Etinson, 2017; Hofstede, 2001; Soydaş Uzunçarşılı, 2010). Ethnocentrism is a behaviour and attitude syndrome that is experienced almost at a universal level and hindering communication between individuals or groups (Hammond \& Axelrod, 2006; Miu, 2016). "The concept of ethnocentrism, one of the most important obstacles of a successful communication at individual and social level, consists of two components. One of them is an individual deeming his own culture as natural, and the other is an individual believing in the superiority of his own culture" (Üstün, 2011, p. 26). Booth (2017, p. 14-15) describes ethnocentrism in three ways. "As a term to describe feelings of group centrality and superiority, As a technical term to describe a faculty methodology in the social sciences, As a synonym for being culture-bound." Individuals may consider cultural behaviours, attitudes, eating habits and clothing that do not conform to their own cultural norms as abnormal, invaluable and even immoral. Such an approach contains subjective behaviours and attitudes that are full of common stereotypes and biases and greatly harm intercultural communication at an individual or social scale (Chalmers, 1996; Güvenç, 2016; Kartarı, 2001; Sargut, 2001; Tekinalp, 2005; Üstün, 2011; Zekiyan, 2015). Just as it is not possible to say one culture is right or better than another, it is also not possible to say a culture is bad or wrong. Some values that are welcomed in a community may not be welcomed in another community. But this cannot mean that certain values are wrong or right (Kırışoğlu, 2009; Ügeöz, 2003; Üstün, 2011). As expressed by De Dreu et al., (2010) and Üstün (2011) the style and level of reflection of ethnocentrism on life is important and in some cases it can help an individual to feel like being a part of a group and develop a positive attachment towards the group, as well as trust, cooperation and coordination within the group. Regardless of the geography or their society, individuals and communities cannot live without being completely purified from the sense of ethnocentrism. But they can try to do their best, through education, individual and social efforts and works (Hofstede, 2001).
Individuals learning about their own cultures and developing awareness about their cultures are among the important factors that increase the success of intercultural communication. An individual who knows his own culture and recognizes his cultural norms and behaviours, would be aware that behaviours are reflections of the values related to a culture, that start right from the childhood. Values that are defined as normal, natural in an individual's culture could be perceived differently in other cultures, or they could be totally meaningless in other cultures. This is the basic rule of intercultural communication and individuals need to possess a certain level of sensitivity for the communication process to be held successfully (Soydaş-Uzunçarşıll, 2010; Ügeöz, 2003). As already expressed by Gürkaynak Çuhadar (2013), getting to know each other and establishing communication are important means of breaking biases and stereotype ideas between individuals and societies. This way, the awareness of individuals or societies regarding their culture increases, while at the same time they start recognizing biases and stereotype ideas as they get to know the similarities and common points with other cultures. From another point of view; developing the ability of living with cultural differences will help addressing obstacles such as ethnocentrism that limit intercultural relations.

\section{Purpose}

The purpose of this study, conducted on the basis of above given thoughts, has been defined as determining whether the education provided has any effects on the ethnocentrism levels of prospective students. With this in mind, answers have been sought for the below given problems and sub-problems.

\section{Problem}

Does the project assignment based on intercultural education have any effect on the ethnocentrism levels of the prospective primary school teachers?

\section{Sub-problems}

1. Is there a significant difference between the "Ethnocentrism Scale" pre-test score averages of the trial and control group students?

2. Is there a significant difference between the "Ethnocentrism Scale" final test score averages of the trial and control group students?

3. Is there a significant difference between the "Ethnocentrism Scale" pre-test / final-test score averages of the trial group students?

4. Is there a significant difference between the "Ethnocentrism Scale" pre-test / final-test score averages of the control group students?

\section{Method}

This section includes the study pattern, study group, data collection tools used in the experimental actions, experimental action process, data collected in the study and the analysis of those data.

\section{Research Pattern}

This study has been designed in accordance to a quasi-experimental design with a pre-test final-test control group. "Quasi-experimental models are preferred in cases where the controls required by true experimental models cannot be met or are insufficient" (Karasar, 2015, p. 104). 


\section{Study Group}

The study group consists of 118 prospective teachers from public universities in Ankara and Niğde. 74 prospective teachers from the Education Faculty Department of Primary School Teaching at a public university in Ankara comprised the trial group. The 44 prospective teachers from the $3^{\text {rd }}$ grade of Education Faculty Department of Primary School Teaching at the university in Niğde comprised the control group.

\section{Method Observed in Application Study}

The application study has been conducted during spring semester of 2014-2015 academic year (14 weeks) with $3^{\text {rd }}$ grade students from the Faculty of Education, Department of Basic Education - Primary School Education of a public university in Ankara. The relevant acquirements of the theme "Power of Visual Culture", selected under the project title "Power of Visual Arts - Intercultural Communication", and the specified classes have been associated under the scope of interdisciplinary approach. Furthermore, the teaching schedule of the project has been established in consideration of the recommendations provided by Banks (2013) and Mahoney \& Schamber (2004).

\section{Stages of Project Application Study}

Formation and Application of the Project Plans: Project study has been formed on the three pillars given below:

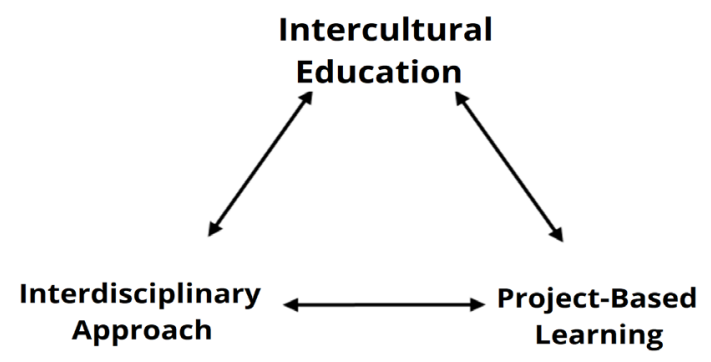

Figure 1. The dimensions used in the study

Under the scope of the project study's theme, the place and relevant acquirements of concepts such as intercultural communication, cultural difference and variety, intercultural awareness, bias, ethnocentrism and stereotype thinking have been examined in relation to the primary school curriculum. It has been observed that the theme is mostly included in the society-related fields of the curriculum such as Visual Arts, Social Sciences, Life Sciences and Turkish Classes. The relevant acquirements of Mathematics Teaching in the curriculum have also been defined as a requirement of the project scope (MoNE, 2014; https:// serc.carleton.edu/sp/library/interdisciplinary/how.html). The acquirements of the class subjects given by placing the Visual Arts Class at the centre have been associated as follows, in line with interdisciplinary approach:

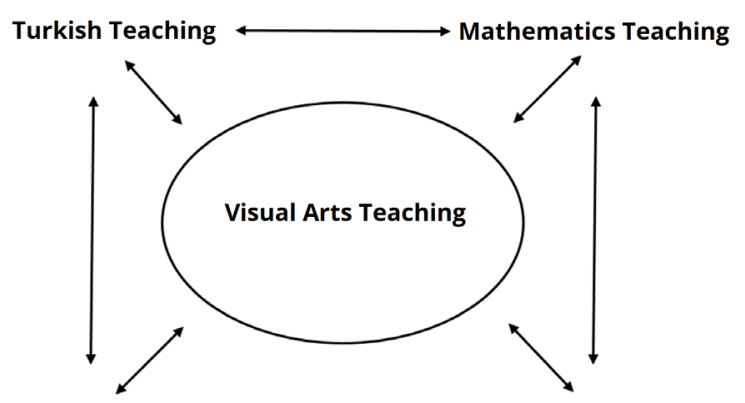

Life Sciences Teaching Social Sciences Teaching

Figure 2. Associating disciplines in the study
At the application stage, the prospective teachers have prepared their presentations indicating the research process and outcomes, forming their project files. In line with the interdisciplinary approach, the acquirements, values and skills have been correlated with the cultural product or art work they were going to work on. During this process, two or three dimensioned products have been created with designs. The project has ended following the exhibition of these products.

\section{Data Collection Tool}

"Ethnocentrism Scale", developed by Neuliep and McCroskey (1997) and adopted into Turkish by Üstün (2011:74 77), has been used as data collection tool. The original format of the scale consists of 22 items and is 5 point Likert type but Üstün (2011) adopted it to Turkish by adding 20 items after doing some works on language equivalence, validity and reliability. The maximum points to be scored in the scale is 100 and the lowest is 20 . Items $4,7,9,12,15$ and 19 of the scale are being scored in reverse. Cronbach Alfa coefficient has been found to be .82 in the reliability study (Üstün, 2011).

\section{Data Analysis}

In order to interpret the points scored in "Ethnocentrism Scale" independent sample t-test and "One-Way Covariance" (One-way ANCOVA) analysis have been used during the pre-test and final test stages of the experimental design of the study (Büyüköztürk, 2010). Analyses have been performed by using SPSS 24.00 package program. Furthermore, Bonferroni correction has been used, which is the preferred correction option in covariance analysis comparisons. The reason behind using the Bonferroni correction is that it is more precise than Sidak (Can, 2014).

\section{Findings}

Findings of the study have been presented in line with sub-problems.

Comparing the "Ethnocentrism Scale" Pre-Test Point Averages Score of Trial and Control Group Students

Table 1. $t$-Test Results for Independent Groups Related to the Ethnocentrism Scale Pre-Test Points of Trial and Control Group Students

\begin{tabular}{ccccccc}
\hline Groups & $N$ & $M$ & $s d$ & $d f$ & $t$ & $p^{*}$ \\
\hline Trial & 74 & 52.43 & 4.41 & 116 & -3.873 & .000 \\
\hline Control & 44 & 55.97 & 5.40 & & & \\
${ }^{*} p<.05$ & & & & & &
\end{tabular}

Table 1 indicates that before the training, the pre-test point average of trial students was $M=52.43$; and the pretest point average of control students was $M=55.97$. This difference between the pre-test points of trial and control group students [t= (116); $p<0.05]$ is significant. This finding is an indication that there is a significant difference between the Ethnocentrism Scale pre-test points of the trial and control group students. In other words, the ethnocentrism level related pre-test points of control group students is much bigger than those of the trial group students. A lower score in ethnocentrism scale indicates a more positive perspective than a higher score. Therefore, the significantly lower pre-test point averages of trial group students at the beginning of the project, when compared to the pre-test point averages of control group students, can be interpreted as trial group students being in a better position in terms of ethnocentrism levels. The formula $d=(\mathrm{MA}-\mathrm{MB}) / \sigma$ is being used for the calculation of the effect size of the resulting difference. While MA-MB represents inter-average difference, 0 is the standard deviation value of difference points. Furthermore, effect size 
values are expressed as .02 small, .05 intermediate and .08 big (Cohen, 1977; Cited by Olkun, Yıldız, Sarı, Uçar, \& Turan, 2014). When the obtained values are put in place in the formula, then $d=(55.97-52.43) / .915=3.86$.

Comparing the Ethnocentrism Scale Final-Test Point Averages of Groups, Corrected on the Basis of Pre-Test Points

As the pre-test points of the trial and control group students were not on the same level in this study, final-test points have been compared by controlling pre-test points of both groups, with the purpose of ensuring the effectiveness of the experimental procedure. The findings of the covariance analysis (ANCOVA) related to the comparison of "Ethnocentrism Scale" final-test point averages of trail and control group students are given in Table 2 .

The averages related to the actual final-test points achieved by the groups in ethnocentrism have been calculated as 51.00 in trial group and 54.68 in control group. The ANCOVA analysis results, conducted to test whether the difference observed between groups on the basis of the corrected average points is meaningful, are given in Table 2:

Table 2. ANCOVA Results of the Ethnocentrism Scale Final-test Points of the Groups Corrected on the Basis of Pre-test Points

\begin{tabular}{ccccccc}
\hline $\begin{array}{c}\text { Variance } \\
\text { Source }\end{array}$ & $\begin{array}{c}\text { Sum of } \\
\text { Squares }\end{array}$ & $d f$ & $\begin{array}{c}\text { Sum of } \\
\text { Squares }\end{array}$ & $F$ & $p^{*}$ & $\eta^{2}$ \\
\hline $\begin{array}{c}\text { Pre-test } \\
\text { (Regression) }\end{array}$ & 0.007 & 1 & .007 & 0.000 & .987 & \\
\hline $\begin{array}{c}\text { Groups } \\
\text { (Final-test) }\end{array}$ & 332.242 & 1 & 332.242 & 11.91 & .001 & .094 \\
\hline Error & 3207.538 & 115 & 27.892 & & & \\
\hline $\begin{array}{c}\text { Total } \\
\text { (Corrected) }\end{array}$ & 3581.593 & 117 & & & \\
\hline${ }^{*} p<.05$ & & & & & & \\
\hline
\end{tabular}

ANCOVA results (Table 2 ) indicate a statistically meaningful difference between the final-test point averages, corrected on the basis of Ethnocentrism Scale pre-test point averages, of the trial group students that are part of the study group of the research $(F(1-115)=27.892, p<.05)$. The $\eta^{2}$ (eta square) value, calculated to reveal the effect of independent variable on the dependent valuable, is .094. Eta square values are interpreted as .10 small, .24 intermediate and .31 large effect (Cohen, 1977; Cited by Sarı \& Tertemiz, 2017).

With this purpose of determining in which group's favour the difference between the corrected final-test points of the groups was, Bonferroni multiple comparison test has been conducted. Results of the Bonferroni test are given in Table 3.

Table 3. Bonferroni Test Results of the Ethnocentrism Scale Final-test Points of the Groups

\begin{tabular}{cccccc}
\hline Groups & Groups & $\begin{array}{c}\text { Difference } \\
\text { Between } \\
\text { Aver. }\end{array}$ & $\begin{array}{c}\text { stand- } \\
\text { ard } \\
\text { error }\end{array}$ & $p$ & $\begin{array}{c}\text { Cause of } \\
\text { Difference }\end{array}$ \\
\hline Trial Control & -3.688 & 1.068 & $\begin{array}{c}1.000 \\
.001^{*}\end{array}$ & Trial>Control \\
\hline${ }^{*} p<.05$ & & & & & \\
\hline
\end{tabular}

According to the Bonferroni multiple comparison test results (Table 3) conducted with the purpose of revealing the differences between the corrected "Ethnocentrism Scale" final-test points of the groups, the experience process in trial group $\left(M_{\text {Trial }}=50.99\right)$ was positively and meaningfully lower than the experience group in control group $\left(M_{\text {control }}=54.68\right)$. This finding indicates that there is a meaningful difference between the "Ethnocentrism Scale" final-test points of the students in trial and control groups. This end-of-the project finding proves that the difference in favour of the trail group in pre-test points continued in the final-test points.

Table 4. t-Test Results of the Ethnocentrism Scale Pre-test and Final-test Average Points of the Groups

\begin{tabular}{cccccccc}
\hline Groups & Measure & $N$ & $M$ & $s d$ & $d f$ & $t$ & $p^{*}$ \\
\hline \multirow{2}{*}{ Trial } & Pre-test & 74 & 52.43 & 4.41 & & & \\
\cline { 2 - 6 } 73 & 102.1 & .001 \\
\cline { 2 - 6 } Control & Final-t. & 74 & 51.00 & 4.83 & & & \\
\cline { 2 - 6 } & Pre-test & 44 & 55.97 & 5.40 & & & \\
\cline { 2 - 5 } & Final-t. & 44 & 54.68 & 5.90 & 68.6 & .001 \\
\hline
\end{tabular}

${ }^{*} p<.05$

Table 4 indicates a significant difference between the point averages before (pre-test) and after (son-test) the experimental procedure in the trial group $\left[t_{(73)}=102.1, p<.05\right]$. The same applies to the control group, where there is a significant difference between pre-test and final-test point averages $\left[t_{(43)}=68.6, p<.05\right]$. In other words, there was a positive-oriented reduction in the ethnocentrism points in the trail group at the end of the experimental procedure. And similarly, there was also a positive-oriented reduction in the ethnocentrism points of the control group at the end of the experimental procedure. Despite the fact that there was a positive development in both groups, the changes in the opinions of the trial group students were significantly different than those of the control group students when groups were compared.

\section{Result and Discussion}

According to the findings of this study where the effects of the education provided under the scope of intercultural education on the ethnocentrism levels of prospective teachers is examined, there has been a positive-oriented change in the ethnocentrism scores of both trial and control group students in group comparisons between their pre and final test point averages. But this change is significant in favour of the trial group in the group comparison. In other words, this project study had a positive impact on the ethnocentrism levels of prospective teachers.

Considering the findings acquired, the study by Demir and Üstün (2017) examining the intercultural awareness and ethnocentrism levels of students in terms of certain variables in various classes is supportive of this current study. The study reports that the training given to the individuals is important in terms of a positive-oriented change in intercultural awareness and ethnocentrism levels. As expressed by Ross (1994), the change of such beliefs are not only affected by education methods but also by active interventions, diversified application of education methods and techniques or application process. In a manner supporting this idea, the prospective teachers participating in our study have expressed their gratitude for conducting a study, making new designs and products by gaining new information about their own cultures and different cultures (Aslantaş \& Tertemiz, 2016). Approaching the matter with a different perspective, Öksüz and Baba Öztürk (2016) reported that the awareness of individuals with regards to cultural differences plays an important role in determining the strategies to be used during the process of overcoming communication disputes. Considering the positive development in the ethnocentrism points of the prospective teachers, it is possible to say that individuals with a high level of awareness about cultural differences would be more constructive when it comes to settling the disputes in the process of intercultural communication, attach importance to strategies that are based on cooperation and distance themselves from behaviour that could lead to insolubility of the issues. Another fact included in the findings was that the prospective teachers generally scored average points in the scale. The findings acquired in 
this study are supportive of Hammond and Axelord's (2006) idea that individuals believe it is difficult to understand, attain a meaning or accept the cultures of different communities through a brief education.

In parallel to Sikorskaya (2017) view that intercultural education should not be provided to migrants or individuals with minority cultures only, but rather to the whole of the society, it is possible to say that through the education provided to the prospective teachers the awareness of the individuals has increased and reached a more positive level in terms of ethnocentrism. Furthermore, as suggested by Bennett (2009) and Perry and Southwell (2011), it is also possible to say that when they become teachers in the future, the current students could be performing intercultural education works that include class contents and activities emphasizing the interaction between their own cultures and different cultures. The possibility that the teachers could be providing similar methods of education to their students in the future may prevent or minimize biases, stereotypes and ethnocentrism that could cause tensions between individuals and societies through the knowledge and abilities they will gain. Even though the theme of this project was intercultural education, bias, stereotypes and ethnocentrism are effected many several other factors too. This can be listed as physical and psychological handicaps, age, gender, economic and social status, race, language spoken, type of education received, place they were raised as well as movie and media sector (Banos, 2006; Bayles, 2009; Boyd, 2015; Çayır \& Ceyhan Ayan, 2013; De et al., 2015; Fretheim, 2007; Gay, 2014; Ryan et. al, 2007; Spinthourakis et al., 2009; Talib ve Hosoya, 2010; Westrick \& Yuen, 2007; Yuen \& Grossman, 2009). The positive oriented development in the control group can be given as an example to this. Even though the education provided was not within the scope of intercultural education, the ethnocentrism points of the control group was also positively developed, even if it was not as much as that occurred in the trial group. Therefore, it is recommended that the issue is addressed in a multi-dimensional way through longterm studies. Similar studies can be conducted with foreign countries under international projects on a long-term and international basis to allow prospective teachers to meet a different culture or cultures and experience different communications. This way it would be possible to conduct projects where intercultural education is studied more actively and individuals can be improved in terms of ethnocentrism.

\section{Refences}

Aslantaş, S. \& Tertemiz Işık, N. (2016). "Görsel kültürün gücü" temalı proje çalışmasına yönelik öğretmen adaylarının görüşleri. [Views of prospective teachers about the project named the power of the visual culture]. Türk Ĕgitim Bilimleri Dergisi, 14(1), 41-68.

Banks, J. A. (2013). Çokkültürlü eğitime giriş. [Introduction to multicultural education] Hasan Aydın (Translated). Ankara: Anı Yayıncılık.

Banos, R.V. (2006). Intercultural sensitivity of teenagers: a study of educational necessities in Catalonia. Intercultural Communication Studies. 15(2), 16-22.

Bayles, P. P. (2009). Assessing the intercultural sensitivity of elementary teachers in bilingual school in Texas school district. Unpublished PHD Thesis, Minnesota University, USA https://www.conservancy.umn.edu/

Bennett, C. (2009). Defining measuring and facilitating intercultural learning a conceptual introduction to the Intercultural Education double supplement. Intercultural Educational, 20(2), 1-13. https://doi. org/10.1080/14675980903370763
Bleszynska, K.M. (2008). Constructing intercultural education. Intercultural Education, 19(6), 537-545, https:// doi.org/10.1080/14675980802568335

Booth, K. (2017). Strategy and Ethnocentrism, online access: https://books.google.com.tr/

Boyd, J. (2015). An examination of native Americans in film and rise of native filmmakers. Elon Journal of Undergraduate Research in Communication, 6(1), 105-113.

Büyüköztürk, Ş. (2010). Sosyal bilimler için veri analizi el kitabı. [Data analysis handbook for social sciences]. Ankara. Ankara: Pegem.

Can, A., (2014). SPSS ile bilimsel araştırma sürecinde nicel veri analizi. [Quantitative data analysis in scientific research process with SPSS]. Ankara: Pegem.

Chalmers, G. F., (1996). Celebrating pluralism: art, education, and cultural diversity. Library of Congress. Cataloguing-in Publication Data, online access: http:// d2aohiyo3d3idm.cloudfront.net/publications/virtuallibrary/0892363932.pdf

Chiriac, A., \& Panciuc, L. (21-25 March 2015). Intercultural education - objectives, values and perspectives. International Conference New Perspectives in Science Education. (edition 4). Italy https://conference.pixel-online.net /

Çayır, K., \& Ceyhan Ayan M. (2013). Ayrımcılık çok boyutlu yaklaşımlar. [Discrimination, multi-dimensional approaches] (2. baskı) Istanbul: Bilgi Üniversitesi Yayınları.

De, S., Gelfand, M.J., Nau, D. \& Roos, P. (2015). The inevitability of ethnocentrism revisited: ethnocentrism diminishes as mobility increases. Scientific Reports. Online publish. 5:17963. https://www.ncbi.nim.gov/pmc/ articles/PMC4672305 /

Demir, S. \& Üstün E. (2017). Öğretmen adaylarının kültürlerarası duyarlılık ve etnikmerkezcilik düzeylerinin çeşitli değişkenler açısından incelenmesi. [Examining the intercultural sensitivity and ethnocentrism levels of prospective teachers in terms of some variables]. Yüzüncü Yıl Üniversitesi Eğitim Fakültesi Dergisi, 14(1), 182-204.

De Dreu C. K., Lindred L. W, Greer, Van Kleef G.A., Shalvi S. \& Handgraaf M. J. J. (2010). Oxytocin promotes human ethnocentrism. PNAS January 25, 2011108 (4) 12621266. https://doi.org/10.1073/pnas.1015316108

Etinson, A. (2017). Some myths about ethnocentrism. Australasian Journal of Philosophy. www.tandfonline. com/doi/abs/.../00048402.2017.1343363?.. /

Fretheim, A. M. (2007). Assessing the Intercultural sensitivity of educators in an American International School. PHD Thesis. USA: Minnesota University. https://search. proquest.com/docview/304823160?pq-origsite=gscholar

Gay, G. (2014). Kültürel değerlere duyarlı eğitim. Teori, araştırma ve uygulama. [Education with an awareness of cultural values. Theory, research and practice] (2. Baskı) Hasan Aydın (Çev). Ankara: Anı Yayıncılık.

Gürkaynak Çuhadar, E. (2013). Toplumsal temas: önyargı ve ayrımcılığı önlemek için bir sosyal değişim aracı olarak kullanılabilir mi? [Social contact: can it be used as a social transformation tool to stop prejudice and discrimination?] Ayrımcılık çok boyutlu yaklaşımlar. Kenan Çayır \& Melek Ayan Dicleli (derleyenler). (2. baskı) İstanbul: Bilgi Üniversitesi Yayınları. 
Güvenç, B. (2016). Insan ve kültür. [Human and culture] (8. baskı). İstanbul: Boyut.

Hammond, R.A. \& Axelrod, R., (2006). The evolution of ethnocentrism. Journal of Conflict Resolution. 50(6). 926-936. journals.sagepub.com/doi/ abs/10.../0022002706293470

Hofstede, G. (2001). Cultural consequences. comparing, values, behaviors, institutions, an organizations across nations. USA: Sage Publications Inc. Online Access: https://books.google.com.tr/books?

Holm G. \& Zilliacus, H. (2009). Multicultural education and intercultural education: is there a difference? M. Talib, J. Loima, H. Paavola \& S. Patrikainen (Eds.) Dialogues on Diversity and Global Education. 11-28 Berlin: Peter Lang. Online Access: https://www. researchgate.net/publication/281555019_Multicultural_education_and_intercultural_education_ Is_there_a_difference

Karasar, N. (2015). Bilimsel Araștırma Yöntemi, [Scientific research method] (28. baskı). Ankara: Nobel Yayın Dağıtım.

Kartarı, A. (2001). Farklııklarla yaşamak. kültürlerarası iletişim. [Living with differences. Intercultural communication] (2. baskı). Ankara: Ürün Yayınları.

Kaya, I.., \& Aydın, H. (2014). Çoğulculuk çokkültürlü ve çokdilli egitim. [Plurality education with multi-culture and multi-language] Ankara: Anı Yayıncılık,

Kırışoğlu, O. T. (2009). Sanat kültür yaratıcılık: görsel sanatlar ve kültür eğitimi-öğretimi. [Art culture creativity: teaching visual arts and culture] (1. baskı). Ankara: Pegem Akademi.

Mahoney, S. L. \& Schamber, J. F. (2004). Exploring the application of a developmental model of Intercultural sensitivity to a general education curriculum on diversity. The Journal of General Education, 53(3-4), 311-334.

MoNE. (2014). Milli Eğitim Bakanlığı Öğretim Programları. [The Ministry of Education Curriculum]. http://mufredat.meb.gov.tr/Programlar.aspx

Miu A. T. (2016). Ethnocentrism - the danger of cultures' collision. Icoana Credintei. International Journal of Interdisciplinary Scientific Research, 2(4), 101-105.

Olkun, S., Yıldız, E., Sarı, M.H., Uçar, A., \& Turan, N.A. (2014). Ortaokul öğrencilerinde işlemsel akıcılık, çarpım tablosu ve sözel problemlerde başarı arasındaki ilişkiler. Illköğretim [Relations between success and procedural fluency, multiplication table and verbal problems in secondary school students. 13(4), 1542-1553. [Online]: http://ilkogretim-online.org.tr doi: $10.17051 /$ io.2014.12588

Öksüz, Y. \& Baba Öztürk M. (2016). Öğretmen adaylarının çatışma eylem stilleri ile kültürlerarası duyarlılık düzeyleri arasındaki ilişki. [The relation between the dispute action styles and the intercultural sensitivity levels of prospective teachers]. Manas Sosyal Araştırmalar Dergisi, 5(4), 1-12

Perry, L.B \& Southwell, L. (2011). Developing intercultural understanding and skills: models and approaches. Intercultural Education, 22(6). 453-466 https://doi. org/10.1080/14675986.2011.644948

Portera. A. (2008) Intercultural education in Europe: epistemological and semantic aspect. Intercultural Education, 19(6), 481-491, DOI:
Ross, J. A. (1994). The impact of an inservice to promote cooperative learning on the stability of teacher efficacy. Teaching and Teacher Education, 10(4), 381394. https://www.citeseerx.ist.psu.edu

Ryan, C.S, Hunt, J.S, Weible, J.A., Peterson, C.R. \& Cases, J. F. (2007). Multicultural and Colorblind Ideology, Stereotypes, and Ethnocentrism among Black and White Americans. Psychology Faculty Publications, 10(4), 617-637. https://doi. org/10.1177/1368430207084105

Sarı, M.H., \& Tertemiz, N. (2017). Ilkokul 4. sınıfta Dienes ilkelerine göre yapılandırılmıs geometri etkinliklerinin öğrenci başarısına ve kalıcılığa etkisi. [The effect of geometry activities, structured upon Diened principles, on the success and permanence of primary school 4th grade students]. Eğitim ve Bilim, 42(190), 1-23. doi: 10.15390/EB.2017.6161

Sargut, A. S. (2001) Kültürler arası farklılaşma ve yönetim. [Intercultural differentiation and management] ( 2 . baskı). Ankara: Imge Kitabevi.

Sikorskaya, I. (2017)Intercultural education policies across Europe as responses to cultural diversity (2006). Centro di Studi Europei, http://www.paperscse. unisa.it

Soydaş Uzunçarşılı, A. (2010) Kültürlerarası iletişim. [Intercultural communication]. Farklı kültürel ortamlarda çalışma ve iletişim. (1. baskı). İstanbul: Parşömen Yayıncılık.

Spinthourakis, J. A., Karatzia-Stavlioti, E. \& Roussakis, Y. (2009). Pre-service teacher intercultural sensitivity assessment as a basis for addressing multiculturalism. Intercultural Education, 20(3), 267-276.

Talib, M. \& Hosoya, S. (2010). Pre-service teachers' intercultural competence in Japan and Finland: A comparative study of Finnish and Japanese university studens- a preliminary study. https://www. researchgate.net /

Tay, B. \& Baş, M. (2015). Çokkültürlü eğitim anlayışı temelli öğrenme-öğretme yaklaşımı, [Teaching-learning approach based on the concept of multicultural education]. Etkinlik Örnekleriyle Güncel ÖğrenmeÖğretme Yaklaşımları-III. 61-95. G. Ekici, (Ed.). https://www.pegem.net

Tekinalp, Ş. (2005). Küreselleşen dünyanın bunalımı: çokkültürlülük. [Depression of globalizing world: multiculturalism]. Journal of Istanbul Kültür University. 2005/1, 75-87.

Tertemiz (Işık), N. \& Aslantaş, S. (2016). Çokkültürlü eğitime dayalı proje çalışmasının sınıf öğretmeni adaylarının kültürlerarası duyarlıık düzeylerine etkisi. [The effects of project work based on multı-cultural education on pre-service teachers' intercultural sencitivity]. Ufuk Üniversitesi Sosyal Bilimler Enstitüsü Dergisi, 5(9), 7-22.

UNESCO (2006). Unesco Guidelines for Intercultural Education. http://unesdoc.unesco.org/images/0014/001478/147878e.pdf

UNESCO (2008). The 2nd UNESCO world report cultural diversity and intercultural dialogue. http://www. unesco.org/new/en/resources/report/the-unesco-worldreport-on-cultural-diversity/

Ügeöz, P. (2003). Kültürlerarası Illetişim [Intercultural communication]. İstanbul: Üstün Eserler Neşriyat Evi. 
Üstün, E. (2011). Öğretmen adaylarının kültürlererası duyarlılık ve etnikmerkezcilik düzeylerini etkileyen etmenler. Yıldız Teknik Üniversitesi Sosyal Bilimler Enstitüsü. www. https://tez.yok.gov.tr

Westrick, J. M. \& Yuen, C.Y.M. (2007). The intercultural sensitivity of secondary teachers in Hong Kong: a comparative study with implications for professional development. Intercultural Education. 18,129-145.

Yuen, C. Y. M. \& Grossman, D.L. (2009) The intercultural sensitivity of student teachers in three cities. Compare. 39(3), 349-365. https://doi. org/10.1080/03057920802281571

Zekiyan, B. L. (2015). Etnik gruplar arası sorunların yeniden ifadesine yönelik bir girişim. [An initiative regarding the re-expression of issues between ethnic groups] Tuncel Öncel (Çev). Mülkiye Dergisi, 39(1), 253-260. https://scholar.google.com.tr/

How to make you classroom interdisciplinary. https://serc carleton.edu/sp/library/ interdisciplinary/how.html / 
Appendix

\begin{tabular}{|c|c|}
\hline & Çatıdaki Kozalaklar \\
\hline $\begin{array}{l}\text { Ilisşkilendirilen Disiplinler ve Ögrrenme Alanları/ } \\
\text { Disciplines Associated and Fields of Learning }\end{array}$ & The Pine On The Roof \\
\hline $\begin{array}{l}\text { MATEMATIK DERSi/MATHS } \\
\text { - Geometry } \\
\text {-Geometrik cisimler / geometric objects } \\
\text {-Örüntü ve süslemeler /patterns and } \\
\text { decorations } \\
\text {-Simetri / symmetry } \\
\text { Üçgen, kare, dikdörtgen / triangle, square, } \\
\text { rectangle } \\
\text { - Ölçme / Measurement }\end{array}$ & $\begin{array}{l}\text { Kastamonu'nun İnebolu ilçesine ait olan İnebolu } \\
\text { Konaklarının çatılarında doğal bir malzeme olan } \\
\text { Marla taşı kullanılır. Bu taşlar Karadeniz'in sert } \\
\text { rüzgarlarına dayanıklı, büyük ve geçmişi çok } \\
\text { eskilere dayanan taşlardır. Bu çalışmada Marla } \\
\text { taşının yapısını ve çatılara döşeniş şeklini, tıpkı bir } \\
\text { kozalağın yapısına benzettim ve insanların bu taşı }\end{array}$ \\
\hline $\begin{array}{l}\text { SOSYAL BILLGILER DERSi/SOCIAL STUDIES } \\
\text { - Birey ve Toplum / Individual and Society } \\
\text { - Kültür ve Miras / Culture and Heritage } \\
\text { - Insanlar, Yerler ve Çevreler / People Places } \\
\text { and Environment }\end{array}$ & $\begin{array}{l}\text { olabileceklerinden esinlendim. Marla taşını ve } \\
\text { kozalağı göz önünde bulundurduğumda tıpkı } \\
\text { avizeye benzeyen, dalından sarkmış kozalağı } \\
\text { andıran ve Marla taşının şeklini barındıran bu özel } \\
\text { çalışmayı ortaya çıkardım. }\end{array}$ \\
\hline $\begin{array}{l}\text { BILIŞiM TEKNOLOJILERI DERSİ/ } \\
\text { INFORMATION TECHNOLOGY } \\
\text { • Bilişim Teknolojilerinin Kullanımı / Usage of } \\
\text { Information Technology }\end{array}$ & \\
\hline $\begin{array}{l}\text { GÖRSEL SANATLAR DERSí/ VISUAL ARTS } \\
\text { • Kültürel Miras / Cultural Heritage }\end{array}$ & $\begin{array}{l}\text { A natural building material, Marla stone is used on } \\
\text { the roof of Inebolu Mansions which belong to }\end{array}$ \\
\hline $\begin{array}{l}\text { TÜRKÇE DERSI/TURKISH } \\
\text { • Görsel Okuma / Visual Reading } \\
\text { • Görsel Sunu / Visual Presentation }\end{array}$ & $\begin{array}{l}\text { İnebolu, province of Kastamonu. These Stones are } \\
\text { big and windproof when considered harsh winds in } \\
\text { the Black sea region. They date back to very old } \\
\text { times.In this study,I assimilated the structure of }\end{array}$ \\
\hline 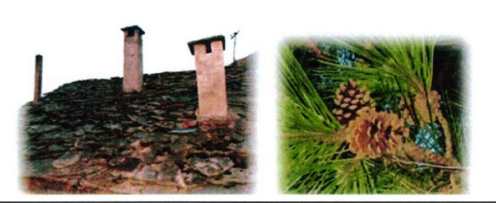 & $\begin{array}{l}\text { Marla stone and its way of being floored to just like } \\
\text { the structure of a pine cone and I thought that } \\
\text { people might be inspired of pine cones when } \\
\text { covering their roofs with Marla Stones. When I } \\
\text { take Marla stone and pine cone into consideration, } \\
\text { I've come up with this special study which looks } \\
\text { exactly like a chandelier, resembles a pine cone } \\
\text { hanging from the branches and containing the }\end{array}$ \\
\hline $\begin{array}{c}\text { Öğrenci-1 /Gazi Eğitim Fakültesi Sınıf Öğretmenliği } \\
\text { 3.Sınıf }\end{array}$ & shape of Marla Stones. \\
\hline
\end{tabular}

\begin{tabular}{|c|}
\hline $\begin{array}{l}\text { İlişkilendirilen Beceri ve Değerler / } \\
\text { Attainments and Merits Associated }\end{array}$ \\
\hline $\begin{array}{l}\text { BECERILER / ATTAINMENTS } \\
\text { - Eleştirel düşünme becerisi / Attainment } \\
\text { of critical thinking } \\
\text { - Yaratıcı düşünme becerisi / Attainment } \\
\text { of creative thinking } \\
\text { - Öz yönetim / Self management } \\
\text { - Iletişim becerisi / Attainment of } \\
\text { communication } \\
\text { - Araştırma becerisi / Attainment of } \\
\text { - } \text { survey } \\
\text { Problem çözme becerisi / Attainment of } \\
\text { problem solving } \\
\text { Karar verme becerisi / Attainment of } \\
\text { dercisin making } \\
\text { - Bilgi teknolojilerini kullanma becerisi / } \\
\text { Attainment of using information } \\
\text { technology } \\
\text { - Zaman ve kronolojiyi algılama becerisi / }\end{array}$ \\
\hline $\begin{array}{l}\text { DEGERLER / MERITS } \\
\text { - Barış/ Peace } \\
\text { - Sorumluluk / responsibility } \\
\text { - Estetik / Aesthetics } \\
\text { - Çalışkanlık / Industriousness } \\
\text { Kültürel Duyarlılık / Sensitivity }\end{array}$ \\
\hline $\begin{array}{l}\text { Öğrenme Alanları 2014-2015 ilköğretim Programından } \\
\text { Alınmış Olup 1-5.sınıf konularına dayalıdır. }\end{array}$ \\
\hline Q⿻ \\
\hline
\end{tabular}

Figure 3. Student 1-Class Flow Chart

\section{İlişkilendirilen Disiplinler ve Öğrenme Alanları/ Disciplines Associated and Fields of Learning \\ GÖRSEL SANATLAR DERSI/VISUAL ARTS \\ - Görsel İletişim ve Biçimlendirme/Visual Communication and Formalization - Kültürel Miras / Cultural Heritage \\ - Sanat Eleştirisi ve Estetik/Art Criticism and Aesthetics}

\begin{tabular}{|l|}
\hline SOSYAL BİLGILER/SOCIAL STUDİES \\
- Kültür ve Miras / Culture and Heritage \\
• İnsanlar Yerler Çevreler / People Places and \\
Environment \\
\hline
\end{tabular}

\begin{tabular}{l}
\hline MATEMATIK/MATHS \\
- Ölçme/Quantification \\
- Geometri/Geometry \\
- Simetri/Symmetry \\
\hline
\end{tabular}

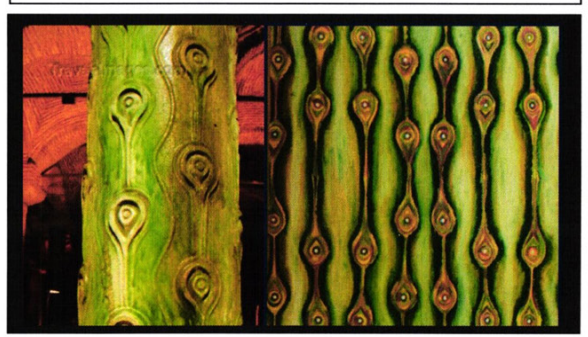

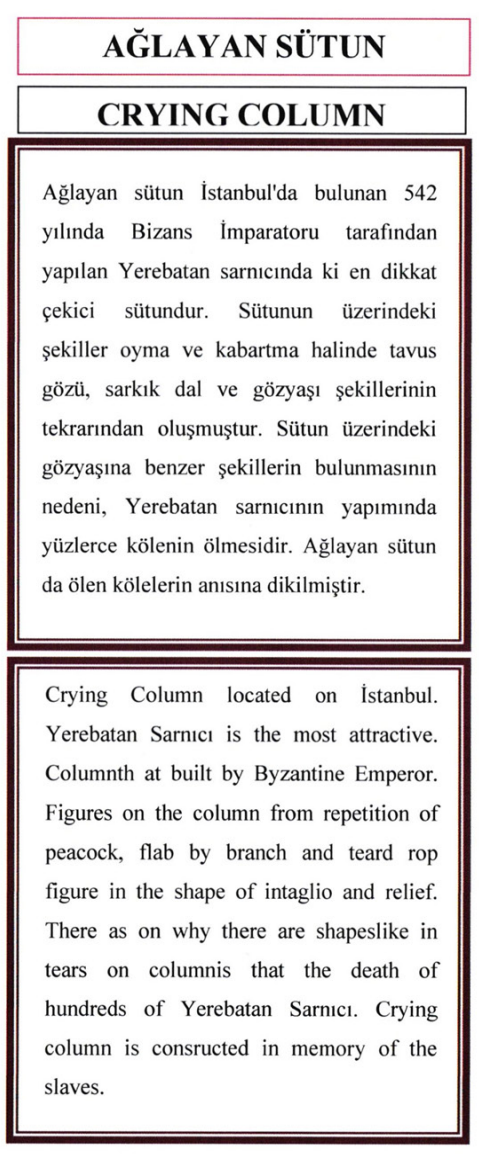

Figure 4. Student 2 - Class Flow Chart

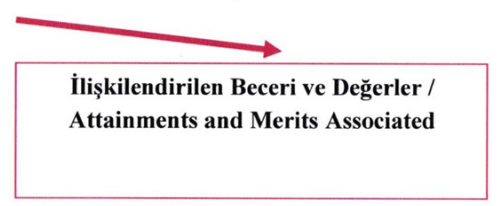

\section{BECERILLER / ATTAINMENTS}

-Yaratıcı Düșünme Becerisi/Attainment of

Critical Thinking

- Araştırma Becerisi / Attainment of Survey

- Gözlem Becerisi/Attainment of

Observation

- Karar Verme Becerisi / Attainmentof

Decision Making

\section{DEĞERLER / MERITS}

- Estetik /Aesthetics

- Bilimsellik/Scienfication

- Çalışkanlık /Industriousness

Öğrenme alanları 2014-2015 İlköğretim

Programından Alınmış Olup 1-5.sınıf Konularına Dayalıdır.

Öğrenci -2-Gazi Eğitim Fakültesi, İlköğretim-Sınıf Öğretmenliği A.B.D 